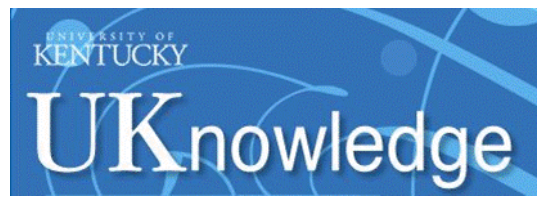

University of Kentucky

UKnowledge

$12-2010$

\title{
Criminal Offending Among Respondents to Protective Orders: Crime Types and Patterns That Predict Victim Risk
}

\author{
Carol E. Jordan \\ University of Kentucky, carol.j@uky.edu \\ Adam J. Pritchard \\ University of Kentucky, adam.pritchard@ucf.edu \\ Danielle Duckett \\ University of Kentucky \\ Richard Charnigo \\ University of Kentucky, richard.charnigo@uky.edu
}

Follow this and additional works at: https://uknowledge.uky.edu/ipsvaw_facpub

Part of the Criminology Commons, Criminology and Criminal Justice Commons, Gender and Sexuality Commons, Psychology Commons, Social Control, Law, Crime, and Deviance Commons, and the Social Work Commons

Right click to open a feedback form in a new tab to let us know how this document benefits you.

\section{Recommended Citation}

Jordan, C.E., Pritchard, A., Duckett, D., \& Charnigo, R. (2010). Criminal offending among respondents to protective orders: Crime types and patterns that predict victim risk. Violence Against Women, 16(12), $1396-1411$

This Article is brought to you for free and open access by the Policy Studies on Violence Against Women at UKnowledge. It has been accepted for inclusion in Office for Policy Studies on Violence Against Women Publications by an authorized administrator of UKnowledge. For more information, please contact UKnowledge@lsv.uky.edu. 


\section{Criminal Offending Among Respondents to Protective Orders: Crime Types and Patterns That Predict Victim Risk}

Digital Object Identifier (DOI)

http://dx.doi.org/10.1177/1077801210389680

\section{Notes/Citation Information}

Published in Violence Against Women, v. 16, no. 12, p. 1396-1411.

The manuscript provided, in accordance with publisher copyright rules, is the authors' postprint version. 


\title{
Criminal Offending Among Respondents to Protective Orders: \\ Crime Types and Patterns that Predict Victim Risk
}

Violence Against Women $X X(X) 1-16$

(C) The Author(s) 2010

Reprints and permission: http://www. sagepub.com/journalsPermissions.nav DOI: I0.1 I77// 07780| 2 | 0389680 http://vaw.sagepub.com

@SAGE

\section{Carol E. Jordan', Adam J. Pritchard', Danielle Duckett', and Richard Charnigo'}

\begin{abstract}
Research has shown that respondents to protective orders have robust criminal histories and that criminal offending behavior often follows issuance of a protective order. Nonetheless, the specific nature of the association between protective orders and criminal offending remains unclear. This study uses two classes of statistical models to more clearly delineate that relationship. The models reveal factors and characteristics that appear to be associated with offending and protective order issuance and provide indications about when a victim is most at risk and when the justice system should be most ready to provide immediate protection.
\end{abstract}

\section{Keywords}

civil justice, criminal histories, intimate partner violence, protective orders

The history of legal reforms on behalf of victims of intimate partner violence has been characterized by a dual-pronged approach of creating and strengthening both criminal and civil legal remedies. Not only have traditional criminal justice statutes on arrest, incarceration, and probation been tailored to intimate partner violence cases through provisions such as warrantless arrest, prohibitions on shock probation, or special conditions of bond, state laws have also been amended to codify civil justice reforms through creation of civil orders of protection. The passage of legislation to enact civil remedies was important to augment the ability of courts and law enforcement to protect victims and their children from

\footnotetext{
'University of Kentucky
}

\section{Corresponding Author:}

Carol E. Jordan, Center for Research on Violence Against Women, University of Kentucky,

108 Bowman Hall, Lexington, KY 40506-0059

Email: carolj@uky.edu 
offenders whose repetitive violent conduct posed substantial risk (Jordan, Nietzel, Walker, \& Logan, 2004). Currently, all states have enacted laws authorizing the issuance of civil or criminal protective orders (Eigenberg, McGuffee, Berry, \& Hall, 2003; U.S. Department of Justice, 2002).

\section{The Association of Criminal Offending Behavior and Civil Protective Orders}

While studies suggest that only a minority of women in general population, criminal justice, and shelter samples access protective orders (Pennell, Burke, \& Mulmat, 2002; Tjaden \& Thoennes, 2000; Weisz, Tolman, \& Bennett, 1998), it is clear they do so after a substantial history of varied forms violence on the part of the offender. Specifically, studies find women seeking protective orders having experienced physical assault (Carlson, Harris, \& Holden, 1999; Gondolf, McWilliams, Hart, \& Stuehling, 1994; Zoellner et al., 2000), beating and choking (Keilitz, Hannaford, \& Efkeman, 1997), threats of harm or death (Klein, 1996; Keilitz et al., 1997; Zoellner et al., 2000), sexual abuse (Ptacek, 1999), and threats with a weapon, stalking, and harassment (Keilitz et al., 1997). Furthermore, most women have experienced lengthy exposure to their partner's violence before reaching out for help. Zoellner et al. reported that $81 \%$ of the women in their study said the incident that prompted them to seek the protective order was not the first incident of abuse, and Harrell and Smith (1996) showed that women had endured abuse for a median of 2.4 years before seeking a protective order. Keilitz et al. found that more than $40 \%$ of women had experienced severe physical abuse at least every few months, and nearly one quarter had suffered abuse for more than 5 years before seeking an order of protection. These data may explain in part why the majority of the time when a woman seeks an emergency (or temporary) protective order from the court, it is granted (Jordan, Pritchard, Wilcox, \& Duckett-Pritchard, 2008).

\section{Criminal Histories Among Respondents to Civil Protective Orders}

Abuse histories this extensive often mean that respondents to protective orders have encountered the criminal justice system prior to the victim seeking a protective order, and in fact past criminal conduct among respondents is not limited to repeated acts of intimate partner violence (Jordan, 2004). Studies on criminal histories among respondents to protective orders find that these offenders tend to commit a range of violent, nonviolent, property, drug, and other offenses. Etter and Birzer (2007) found an extensive history of criminal offending and high recidivism in the histories of respondents to protective orders in one county population. Specifically, $73.3 \%$ of respondents had prior misdemeanor arrests and 79\% had prior felony arrests. Similarly, Klein (1996) reported that almost 80\% of respondents had prior criminal histories with the offenders on average having been in court for six separate incidents. Kethineni and Falcone (2001) reported that $75.3 \%$ of respondents had charges against them, almost two thirds of which were domestic violence 
charges, and another $18.8 \%$ were other violent felony charges. Keilitz et al. (1997) reported that $65 \%$ of respondents to protective orders had histories involving violent crimes, and nearly one half of the $75 \%$ of respondents who had criminal histories in a study by Isaac, Cochran, Brown, and Adams (1994) had histories of violent crimes.

In addition to studies revealing a robust positive relationship between criminal histories and protective orders, research suggests that offenders with criminal histories are more likely to reabuse the victim (Buzawa, Hotaling, \& Klein, 1998; Kethineni \& Beichner, 2009; Klein, 1996). Harrell and Smith (1996) found that the severity of prior abuse experienced by a woman who sought a protective order was significantly related to the severity of abuse she experienced in the year after the order was issued. The finding is consistent with the research on arrest efficacy done by Maxwell, Garner, and Fagan (2001), who reported that having one or more prior arrests for any offense against any victim is consistently associated with more new incidents of abuse, and in fact "suspects with prior arrests for any offense are from $250 \%$ to $330 \%$ more likely to commit new acts of intimate partner violence" (p. 73).

\section{Patterns of Criminal Offending Following Issuance of a Protective Order}

Before analysis of offending patterns following issuance of a protective order can occur, several characteristics of the justice system must be considered. First, not all reoffending behavior on the part of an offender (either in violation of the order's conditions or for unrelated crimes) will be reported to or even known by police. In fact, there is evidence that less than half of all incidents of violence against women by intimates are ever reported (Bachman, 1994). Even lower rates of contacting police were found by Kantor and Straus (1990), who reported that as few as $7 \%$ to $14 \%$ of intimate partner assaults are reported to the police. Studies that examine why women who have temporary orders of protection fail to pursue permanent orders shed light on this reporting phenomenon. Specifically, a number of studies suggest that a primary reason women do not seek permanent help is because they fear retaliation on the part of the offender (Chaudhuri \& Daly, 1992; Ferraro, 1997; Mears, Carlson, Holden, \& Harris, 2001; Zoellner et al., 2000), a pressure that may well be at play as women do not report violations of their orders.

In addition to low reportage rates among victims, there is also evidence of low arrest rates by law enforcement officers in response to subsequent criminal behavior by a respondent, either behavior that violates the order of protection or other criminal conduct. In fact, research finds extremely low rates of arrest of intimate partner violence offenders following reported criminal offending, ranging from $5 \%$ to $36 \%$ of cases (Baker, Cahn, \& Sands, 1989; Bourg \& Stock, 1994; Buzawa \& Hotaling, 2000; Ferraro, 1997; Mignon \& Holmes, 1995; Robinson \& Chandek, 2000). This pattern is true even when victims' reports included physical injury from the assault. For example, Smith (2001) found that whereas more than $60 \%$ of the cases involved physical injury to the victim, only $28 \%$ resulted in arrest. Studies that focus specifically on arrest for violations of the conditions of protective orders also 
find relatively low arrest rates. Klein (1996) found that only $34 \%$ of respondents who violated orders were arrested, and Kane (2000) reported that only 44\% of protective order violations resulted in arrest. Harrell and Smith (1996) found that the arrest rate in cases of intimate partner violence where protective orders were violated was only $20 \%$.

Studies on the effectiveness of civil protective orders often use the measure of criminal offending behavior following issuance of a protective order. These studies paint a mixed picture of protective order effectiveness. A number of studies find low rates of protective order violations. For example, Kaci (1994) found that up to $92 \%$ of victims reported that the violence stopped after the protective order was issued; Carlson et al. (1999) found a 66\% decrease in violence 2 years following the issuance of the order; Holt, Kernic, Lumley, Wolf, and Rivara (2002) found that having a permanent protective order in place was associated with a significant $80 \%$ reduction in police-reported physical violence in the 12 months following the initial incident; and McFarlane et al. (2004) found that the 149 women in their study reported significantly lower levels of intimate partner violence for up to 18 months following issuance of the order. Notably, however, while reporting lower levels of overall violence, $44 \%$ of the women in the McFarlane et al. study reported at least one violation during the 18 months studied.

Not all studies report low rates of offender recidivism associated with protective orders. Spitzberg (2002) conducted a meta-analysis of 32 studies and found that orders were violated approximately $43 \%$ of the time, and in 9 studies an escalation of violence or stalking followed issuance of a protective order approximately $21 \%$ of the time. Harrell and Smith (1996) reported a $60 \%$ rate of reabuse in a 2 -year follow-up, including severe violence $(29 \%)$, other physical violence (24\%), threats of violence and acts of property damage (43\%), and psychological abuse (57\%). In a 2-year follow-up study of offenders, Klein (1996) found that almost half $(48.8 \%)$ of protective order respondents reabused the victim after the issuance of a protective order, and in a 13-month follow-up study, Logan and Walker (2009) found that $58 \%$ of women experienced a violation of the protective order. Logan and colleagues also noted that whereas overall $58 \%$ of women were classified as having experienced a protective order violation, a larger percentage (68\%) who continued a relationship with the abusive partner experienced reabuse than did those who did not continue the relationship (53\%; Logan, Walker, Shannon, \& Cole, 2009).

\section{The Present Study}

Research has repeatedly shown that respondents to protective orders have robust criminal histories and that criminal offending behavior often follows issuance of a protective order. Nonetheless, the specific nature of the relationship between civil orders of protection and criminal offending behavior remains unclear. If one looks only at acts of violence following issuance of a protective order, as studies gauging the effectiveness of this legal remedy typically do, it is not possible to assess whether the protective order's existence influenced future offending behavior or whether the offender's past criminal conduct was the more significant influence. And, in fact, as Jordan (2004) noted, "Measuring protective order 
effectiveness strictly by temporary recidivism has the problematic artifact that the abuse may have ended for reasons other than the order" (p. 1427). A further weakness in the extant literature is in understanding the nature of the criminal offending behavior that precedes issuance of a protective order. While studies often categorize prior crimes by misdemeanor, felony, or violent crime categories, a temporal relationship between patterns of criminal offending and issuance of orders has not been adequately studied. This lack of a more nuanced and clear understanding of the relationship between respondent offending patterns and protective orders leaves researchers unable to assess the effectiveness of civil protection and the justice system less capable of extending the most efficacious protection to victims of intimate partner violence.

The purpose of this study is to address a major gap in the literature on the relationship between criminal offending patterns and protective orders by examining the temporal relationship between the two. Specifically, the aims of the study are to explore (a) the predictive ability of the pattern and type of offending behavior vis-à-vis the protective order, and (b) the impact of protective orders on future offending behavior.

\section{Method}

To examine the temporal relationship between criminal activity and the issuance of protective orders, this study examines data about individuals against whom protective orders have been filed. In accordance with a mandate from the state legislature, the Kentucky Supreme Court and the Administrative Office of the Courts (AOC) have maintained records of the protective order system in the state since 1994. This database was utilized in the present study to identify respondents against whom protective orders were filed during FY2003. According to AOC records, 28,075 cases related to protective orders were opened in the state of Kentucky in FY03. A listing of 2,361 protective order case files was compiled based on a $10 \%$ random sample of all protective orders filed during the fiscal year. Because some cases involve multiple protective orders, or because some respondents did not have complete records available, the case sample ultimately represents $8.4 \%$ of all protective order cases opened during FY03. After identifying the sample cases, in-state criminal histories of respondents against whom protective orders were filed (respondents) were requested from Pretrial Services Agency who compiled criminal and domestic violence records as available in AOC/CourtNet records. Nonfelony traffic charges (i.e., speeding and insurance coverage fines) were excluded from subsequent analyses because no conceptual relationship exists between minor traffic charges and the perpetration of domestic violence, and including these charges could effectively mask more meaningful patterns in the data. Except for details of the charges themselves, CourtNet information about respondents was limited to age, race, and gender.

Criminal history records accessed for the study encompassed 2,073 individual respondents who together accounted for 3,445 protective orders, 16,407 criminal charges, and 12,693 traffic charges. For each criminal charge brought against a respondent the date, nature of the charge, action by the court, and disposition of the charge were recorded. 
Table I. Classifications of Criminal Charges

\begin{tabular}{ll}
\hline Variable & \multicolumn{1}{c}{ Categories } \\
\hline Criminal Charge & No Charges \\
Felony crime involving death or attempted murder of victim \\
Felony crime involving physical assault of victim \\
Felony stalking \\
Felony crime involving sexual violence/abuse against victim \\
Other felony crimes \\
Misdemeanor crime involving assault of victim \\
Misdemeanor stalking \\
Misdemeanor sex offense/other offense against minor \\
Other misdemeanor crimes \\
Weapons offense \\
Property offense \\
Other harassing/threat crime against persons \\
Offense related to action against police officers or court officials \\
Alcohol/drug offense \\
Local ordinance \\
Violation of protective order
\end{tabular}

Charges recorded for analysis purposes were sorted into several categories (see Table 1). Additionally, dates of protective order filing and court actions related to protective orders were recorded, allowing this study to directly compare the timing of criminal charges to the timing of protective orders.

Statistical modeling took place in two phases. In Phase 1 we fit several multiplicative hazards models to identify factors that predicted issuance of protective orders. These models provided estimates of how likely respondents were to receive protective orders in the next month based on one or more of several factors, including the number and nature of the respondents' criminal activities as well as their demographic characteristics. In Phase 2 we fit several logistic regression models to identify factors that predicted the issuance of charges following protective orders. These models provided estimates of how likely respondents were to receive charges in a given month based on one or more of several factors, including how much time had passed since the respondents' most recent protective orders as well as their demographic characteristics. We used Version 9.1 of SAS (SAS Institute, Cary, NC) to perform the statistical modeling. Variables for the multifactor model in Phase 1 were selected, using a stepwise algorithm with significance threshold .05 , from the pool of variables generating $p$ values less than .20 for the single-factor models. Generalized estimating equations were used to estimate parameters in Phase 2 due to the correlations among repeated measurements on the same respondents. A $p$ value less than .05 was regarded as statistically significant. 


\section{Results}

There were several noteworthy aggregate demographic characteristics for this sample. First, $79.5 \%(n=1,649)$ of the sample respondents were men. With respect to race, $82.5 \%$ of the sample $(n=1,710)$ were classified as White/Caucasian; African Americans comprised $15.2 \%(n=315)$, and all other racial groups together accounted for only $2.3 \%(n=48)$ of the sample. The mean age of the overall sample was 35.15 years $(S D=10.73)$; however, African American respondents (mean age $=33.09$ years, $S D=9.40$ ) were significantly younger on average than Caucasian (mean age $=35.46$ years, $S D=10.91$ ) respondents $(F=13.177, p<.001)$. In addition, African American respondents were significantly more likely to have been charged with a violent crime compared to Caucasians $-61.3 \%$ vs. $41.2 \% ; \chi^{2}(1)=43.29, p=.000$. The average age at time of first nontraffic criminal charge was 27.47 years $(S D=9.64)$.

Approximately $43.9 \%$ of protective order respondents had been previously charged with a violent offense $(n=910)$, whereas only $20.1 \%$ had never been charged with a crime $(n=417)$. Important aggregate patterns emerged between the frequency of protective order filing and the nature of other criminal offenses with which respondents were charged. For example, significantly more protective orders, on average, were filed against respondents who had stalking charges, sexual charges, or harassing charges than individuals who did not have any of these charges.

Respondents charged with stalking have a significantly higher number of protective order petitions filed against them $(M=2.44$ protective orders, $S D=1.629$ protective orders) when compared to respondents without stalking charges $(M=1.65$ protective orders, $S D=$ 1.144 protective orders). One way ANOVA testing indicates that this difference is significant at the .05 level, $F(1)=16.840, p=.000$. Respondents charged with sexual offenses have a significantly higher number of protective order petitions filed against them $(M=$ $2.26, S D=1.755)$ compared to respondents without sexual offense charges $(M=1.62$, $S D=1.093)$. One-way ANOVA testing indicates that this difference is significant at the .05 level, $F(1)=7.110, p=.000$. Respondents charged with harassing or threat crimes had a significantly higher number of protective order petitions filed against them $(M=2.09$ petitions, $S D=1.510$ petitions) compared to respondents without harassing or threat crime charges ( $M=1.41$ petitions, $S D=0.792$ petitions). One-way ANOVA testing shows this difference to be significant at the .05 level, $F(1)=180.605, p=.000$. Respondents charged with harassing or threat crimes have a significantly higher proportion of protective order petitions end with the granting of a domestic violence order compared to respondents without harassing or threat crime charges, $F(1)=4.624, p=.032$.

This study aimed to move beyond associations of protective orders and criminal history to explore the impact of protective orders on future offending behavior and the predictive ability of the pattern and type of offending behavior as they relate to subsequent issuance of a protective order. The statistical modeling in Phases 1 and 2 permitted assessment of that more detailed relationship. We now describe the findings from Phase 1, which address the question of which criminal behavior patterns precipitate new protective orders. We fit 15 single-factor multiplicative hazards models, one for each of the 15 variables in Table 2. 
Table 2. Phase I: Single-Factor Multiplicative Hazards Models

\begin{tabular}{|c|c|c|}
\hline Explanatory variable & $\begin{array}{l}\text { Estimated change in the likelihood } \\
\text { of being issued a protective order } \\
\text { in the next month }\end{array}$ & $p$ value \\
\hline Any criminal charge & Increases by $0.6 \%$ per charge & .0070 \\
\hline Number of criminal events where charged & Increases by $1.4 \%$ per occurrence & .0005 \\
\hline $\begin{array}{l}\text { Number of criminal events with a } \\
\text { PO-related charge }\end{array}$ & Increases by $30.7 \%$ per occurrence & $<.0001$ \\
\hline $\begin{array}{l}\text { Number of events with at least one felony } \\
\text { charge }\end{array}$ & Decreases by $0.7 \%$ per occurrence & .5553 \\
\hline $\begin{array}{l}\text { Number of events with at least one crime } \\
\text { against person(s) charge }\end{array}$ & Increases by $0.6 \%$ per occurrence & .2738 \\
\hline $\begin{array}{l}\text { Number of events for which jail time was } \\
\text { served }\end{array}$ & Increases by $3.5 \%$ per occurrence & $<.0001$ \\
\hline $\begin{array}{l}\text { Number of events where subject was } \\
\text { found guilty of at least one charge }\end{array}$ & Increases by $0.7 \%$ per occurrence & .2768 \\
\hline $\begin{array}{l}\text { Number of events where the most serious } \\
\text { charge was a felony or misdemeanor } \\
\text { sex offense or misdemeanor assault or } \\
\text { misdemeanor stalking }\end{array}$ & Increases by $14.0 \%$ per occurrence & $<.0001$ \\
\hline $\begin{array}{l}\text { Number of events when two or more } \\
\text { charges were filed }\end{array}$ & Increases by $6.0 \%$ per occurrence & $<.0001$ \\
\hline $\begin{array}{l}\text { Number of events when three or more } \\
\text { chargers were filed }\end{array}$ & Increases by $6.7 \%$ per occurrence & .0041 \\
\hline $\begin{array}{l}\text { Number of events when four or more } \\
\text { charges were filed }\end{array}$ & Increases by $4.3 \%$ per occurrence & .1986 \\
\hline $\begin{array}{l}\text { Number of events for which jail time was } \\
\text { served for a crime against person(s) }\end{array}$ & Increases by $1.5 \%$ per occurrence & .1661 \\
\hline Age & Decreases by $0.2 \%$ per year of age & .3370 \\
\hline Gender & $12.8 \%$ larger for women & .0544 \\
\hline Race & $4.0 \%$ smaller for racial minorities & .4402 \\
\hline
\end{tabular}

Seven of the 15 variables were associated with significant increases in the likelihood of a protective order being issued. All percentage increases reported in the following paragraphs are estimates based on the multiplicative hazards models.

The largest effect on the likelihood of a new protective order being issued within the next month following a charge or group of charges occurred when there was a violation of a previous protective order. When this was the case, the likelihood of a subsequent protective order was increased by $30.7 \%$ per violation $(p<.0001)$.

The second largest effect on the likelihood of the issuance of a subsequent protective order was when the respondent received one of these key charges: felony, misdemeanor sex offense, misdemeanor assault, or misdemeanor stalking. The likelihood of a protective 
Table 3. Phase I: Multifactor Multiplicative Hazards Model

\begin{tabular}{llll}
\hline Explanatory variable & $\begin{array}{l}\text { Estimated change in the likelihood } \\
\text { of being issued a protective order } \\
\text { in the next month, controlling for } \\
\text { the other explanatory variables }\end{array}$ & p value \\
\hline $\begin{array}{l}\text { Number of criminal events with a } \\
\text { PO-related charge }\end{array}$ & Increases by 25.3\% per occurrence & $<.000$ I \\
$\begin{array}{l}\text { Number of events where the most serious } \\
\text { charge was a felony or misdemeanor } \\
\text { sex offense or misdemeanor assault or } \\
\text { misdemeanor stalking }\end{array}$ & Increases by 13.0\% per occurrence & $<.000$ I \\
\begin{tabular}{l} 
Gender \\
\hline
\end{tabular} & 14.8\% larger for women & .0278 \\
\hline
\end{tabular}

order the subsequent month increased by $14.0 \%$ per occurrence $(p<.0001)$. This effect was specific to these particular charges, as neither felony offenses alone nor both the number of felony offenses $(p=.5553)$ and the number of crimes against persons $(p=.2738)$ significantly the likelihood of a protective order.

A third effect on the likelihood of a protective order being issued in the next month is derived from the presence of a "cluster" of charges issued simultaneously. A single cluster of 2 or more charges raised the likelihood of a protective order by $6.0 \%(p<.0001)$, whereas a single cluster of 3 or more charges raised the likelihood of a protective order by $6.7 \%(p=.0041)$. These effects compounded with multiple clusters, so, for example, 2 clusters of 3 or more charges increased the likelihood of a protective order by $13.8 \%(1.067 \mathrm{x}$ $1.067=1.138)$. Also, for every charge that resulted in jail time, the likelihood of a protective order being issued against the offender increased by $3.5 \%(p<.0001)$. When all variables achieving $p$ values less than .20 in single-factor multiplicative hazards models were entered into a stepwise selection algorithm with significance threshold at .05 , the resulting multifactor multiplicative hazards model contained three variables.

Table 3 shows the effect of each of these variables while controlling for the other two. Each previous protective order violation increased the likelihood of a new protective order by $25.3 \%(p<.0001)$ when controlling for the number of occasions with "key charges" and gender, while each occasion with a "key charge" increased the likelihood of a new protective order by $13.0 \%(p<.0001)$ when controlling for the number of previous protective order violations and gender.

In Phase 2 we examined the other side of the relationship between criminal changes and protective orders. Namely, how does the likelihood of incurring a charge depend on the length of time since the most recent protective order? All percentage changes reported in the following paragraphs are estimates based on the logistic regression models. A singlefactor logistic regression model showed that the odds of being charged in the month after the most recent protective order were $25.8 \%$ smaller than the odds of being charged in the same month as the most recent protective order, the odds of being charged at 7 months 
Table 4. Phase 2: Single-Factor Logistic Model

\begin{tabular}{lcc}
\hline Comparison & $\begin{array}{c}\text { Estimated change in odds of } \\
\text { being charged in a given month, } \\
\text { based on time since the most } \\
\text { recent protective order (\%) }\end{array}$ & $\begin{array}{c}95 \% \text { confidence } \\
\text { interval }\end{array}$ \\
\hline 0 months since to I month since & -25.8 & -27.8 to -23.7 \\
6 months since to 7 months since & -13.9 & -14.7 to -13.1 \\
I2 months since to I3 months since & -5.2 & -6.0 to -4.4 \\
I8 months since to I9 months since & +0.3 & -0.8 to +1.3 \\
24 months since to 25 months since & +2.9 & +2.0 to +3.9 \\
30 months since to 3 I months since & +3.5 & +2.7 to +4.3 \\
36 months since to 37 months since & +2.7 & +1.8 to +3.5 \\
42 months since to 43 months since & +1.1 & +0.1 to +2.2 \\
48 months since to 49 months since & -0.5 & -1.7 to +0.7 \\
54 months since to 55 months since & -1.9 & -3.1 to -0.7 \\
60 months since to 6 I months since & -2.8 & -4.0 to -1.6 \\
\hline
\end{tabular}

were $13.9 \%$ smaller than at 6 months, and the odds of being charged at 13 months were $5.2 \%$ smaller than at 12 months (Table 4). Offenses became less likely as more time passed since the most recent protective order, up to about 18 months, after which offenses became more likely. This trend remained robust for a multifactor logistic regression model that controlled for the offender's age, gender, race, and the number of previous protective orders filed against that person (see Table 5).

In Phase 2 we also examined how the likelihood of being charged varied with demographic factors of the respondent. The following results were obtained from singlefactor logistic regression models. For every additional decade of age, the odds of being charged with a crime following a protective order decreased by $33.3 \%(p<.0001)$. Women had odds $46.2 \%$ smaller of being charged with a crime than men did $(p<.0001)$. Non-White respondents had odds $42.2 \%$ larger than Whites of being charged with a crime $(p<.0001)$. Interestingly, the number of previous protective orders accumulated in the respondent's lifetime only increased the odds of a criminal charge by $3.9 \%$ per protective order, a result that was not significant $(p=.0955)$.

We also constructed a multifactor logistic regression model that included age, race, gender, previous protective orders, and time since the most recent protective order. Controlling for other variables in the model, each decade of age decreased the odds of charges by $27.2 \%$ ( $p<.0001)$; women had $45.5 \%$ smaller odds than men of being charged $(p<.0001)$, and non-White offenders had 33.4\% larger odds of being charged than Whites $(p<.0001)$. Moreover, when controlling for other variables, the odds of facing charges increased by $6.4 \%$ per previous protective order $(p=.0146)$. This suggests that younger, non-White, male respondents with prior protective orders are more likely to accrue criminal charges after a new protective order is issued. 
Table 5. Phase 2: Multifactor Logistic Regression Model.

\begin{tabular}{|c|c|c|}
\hline Comparison & $\begin{array}{l}\text { Estimated change in odds } \\
\text { of being charged in a given } \\
\text { month, based on time since } \\
\text { the most recent protective } \\
\text { order, controlling for other } \\
\text { explanatory variables (\%) }\end{array}$ & $\begin{array}{c}95 \% \text { confidence } \\
\text { interval }\end{array}$ \\
\hline 0 months since to I month since & -25.6 & -27.5 to -23.6 \\
\hline 6 months since to 7 months since & -13.8 & -14.6 to -13.0 \\
\hline 12 months since to 13 months since & -5.1 & -5.9 to -4.3 \\
\hline 18 months since to 19 months since & +0.4 & -0.6 to $+\mathrm{I} .3$ \\
\hline 24 months since to 25 months since & +3.0 & +2.1 to +3.9 \\
\hline 30 months since to 31 months since & +3.5 & +2.8 to +4.3 \\
\hline 36 months since to 37 months since & +2.7 & +1.9 to +3.5 \\
\hline 42 months since to 43 months since & +1.2 & +0.2 to +2.2 \\
\hline 48 months since to 49 months since & -0.4 & -1.5 to +0.7 \\
\hline 54 months since to 55 months since & -1.8 & -2.9 to -0.6 \\
\hline 60 months since to 61 months since & -2.6 & -3.7 to -1.4 \\
\hline
\end{tabular}

\section{Discussion}

The goal of this study was to create a more detailed understanding of the relationship between criminal offending and protective orders. The study's specific aims were to explore the impact of protective orders on future offending behavior and to determine how the pattern and type of offending behavior relates to subsequent issuance of a protective order. To accomplish this goal, two phases of statistical modeling were carried out. Phase 1 explored the pattern of criminal behavior by an individual prior to a protective order being issued. Phase 2 examined how the likelihood of incurring more charges varied with the amount of time since the most recent protective order.

Phase 1 revealed three important characteristics of the relationship between prior criminal offending and the issuance of a protective order, characteristics that should also be viewed as risk markers for victims. First, the likelihood of a subsequent protective order being issued within the next month was increased by $30.7 \%$ per violation of a previous protective order. This finding is somewhat intuitive; the violation of a protective order indicates an ongoing pattern of domestic abuse that, if the violator does not end up serving jail time, would constitute evidence of a need for a further (or renewed) order. The pattern also emphasizes the cyclical nature of violence and the continuation risk to victims and points to a need for renewals of protective orders to be an accessible and straightforward process for victims. In addition to the key role of protective order violations as a predictor of risk, this study also found that the likelihood of a subsequent 
protective order being issued increased by $14.0 \%$ per occurrence involving a felony, misdemeanor sex offense, misdemeanor assault, or misdemeanor stalking. These findings build on extant research that reveals an association with criminal histories and violations of orders (e.g., Kethineni \& Beichner, 2009) by illuminating the type of offense patterns that may reveal the most risk. Specifically, it appears that the need for a future protective order is associated most closely with prior commission of specific types of offenses; those prior offenses are related to physical or sexual assault or harassment of the victim. This finding is consistent with the finding from Logan and Walker (2009) that stalking is a significant predictor of protective order violations. Our identifying these types of criminal offenses may also reflect the increased likelihood of a court to respond affirmatively to a request for a protective order when these types of offenses have been committed. The third factor affecting later issuance of a protective order goes beyond the type of offense and focuses on the pattern of offending. Specifically, the likelihood of a protective order being issued increased by $6.0 \%$ per cluster of 2 or more charges and $6.7 \%$ per cluster of 3 or more charges $(6.0 \%-6.7 \%)$. In addition, for every charge that resulted in jail time, the likelihood of a protective order being issued against the offender increased by $3.5 \%$. This pattern of high rates of offending within a concentrated period of time may help identify periods when victims are particularly at risk and thus in need of protective orders.

Phase 2 was designed to answer whether the likelihood of an individual incurring more charges varies with the amount of time since the most recent protective order. The extant literature often measures the rate of violation of orders, and this study looked specifically at whether the respondent commits additional crimes in the months following the order's issuance. The findings here suggest that less offending occurs as more time passes since the most recent protective order, up to about 18 months, after which more offending occurs. Hence, the deterrent effects of protective orders seem to weaken after about 18 months. Phase 2 also sheds light on the characteristics of the offenders who are most likely to engage in criminal behavior after a protective order was issued, suggesting that younger, nonWhite, men are more likely to accrue criminal charges after a new protective order is issued. In addition, another factor that emerges is the number of prior protective orders, with a greater number of these linked to more criminal charges.

\section{Conclusion}

This study provides clearer focus on the relationship between criminal offending behavior and the issuance of protective orders. Both the type and pattern of criminal offending behavior are related to issuance of a protective order: Offenders who commit sexual offenses, physical assaults, and stalking, particularly when those offenses are clustered together in time, are more likely to draw protective orders. As such, these factors are predictive of a victim's risk of harm. There is also evidence from this study that cases involving prior violations of protective orders and jail time are ones in which later issuance of a protective order is likely. Those most likely to offend subsequent to a protective 
order's issuance include young, non-White, and male respondents, especially those against whom several prior protective orders have been issued.

This study provides key insights into the civil and criminal justice systems and to victim advocates regarding those offenders who pose the greatest risk of reoffending against a survivor of intimate partner violence.

\section{Declaration of Conflicting Interests}

The author(s) declared no potential conflicts of interest with respect to the authorship and/or publication of this article.[AQ:1]

\section{Funding}

The author(s) received no financial support for the research and/or authorship of this article.

\section{[AQ: 2]}

\section{References}

Bachman, R. (1994). Violence against women (NCJ 145325). Washington, DC: U.S. Department of Justice.

Baker, K., Cahn, N., \& Sands, S. J. (1989). Report on District of Columbia police response to domestic violence. Washington, DC: D.C. Coalition Against Domestic Violence and the Women's Law and Public Policy Center, Georgetown University Law Center.

Bourg, S., \& Stock, H. V. (1994). A review of domestic violence statistics in a police department using a pro-arrest policy: Are pro-arrest policies enough? Journal of Family Violence, 9, 177-189.

Buzawa, E., \& Hotaling, G. (2000). The police response to domestic violence calls for assistance in three Massachusetts towns: Final report. Washington, DC: National Institute of Justice.

Buzawa, E., Hotaling, G., \& Klein, A. (1998). The response to domestic violence in a model court: Some initial findings and implications. Behavioral Sciences and the Law, 16, 185-206.

Carlson, M. J., Harris, S. D., \& Holden, G. W. (1999). Protective orders and domestic violence: Risk factors for re-abuse. Journal of Family Violence, 14, 205-226.

Chaudhuri, M., \& Daly, K. (1992). Do restraining orders help? Battered women's experience with male violence and legal process. In E. Buzawa \& C. Buzawa (Eds.), Domestic violence: The criminal justice response (pp. 227-252). Thousand Oaks, CA: Sage.

Eigenberg, H., McGuffee, K., Berry, P., \& Hall, W. H. (2003). Protective order legislation: Trends in state statutes. Journal of Criminal Justice, 31, 411-422.

Etter, G. W., \& Birzer, M. L. (2007). Domestic violence abusers: A descriptive study of the characteristics of defenders in protection form abuse orders in Sedgwick County, Kansas. Journal of Family Violence, 22, 113-119.

Ferraro, K. J. (1997). Battered women: Strategies for survival. In A. P. Cardarelli (Ed.), Violence between intimate partners: Patterns, causes and effects (pp. 124-143). Boston: Allyn \& Bacon. 
Gondolf, E., McWilliams, J., Hart, B., \& Stuehling, J. (1994). Court response to petitions for civil protection orders. Journal of Interpersonal Violence, 9, 503-517.

Harrell, A., \& Smith, B.E. (1996). Effects of restraining orders on domestic violence victims. In E. Buzawa \& C. Buzawa (Eds.), Do arrests and restraining orders work? (pp. 214-242). Thousand Oaks, CA: Sage.

Holt, V. L., Kernic, M. A., Lumley T., Wolf, M. E., \& Rivara, F. P. (2002). Civil protection orders and risk of subsequent police-reported violence. Journal of the American Medical Association, 288, 589-594.

Isaac, N., Cochran, D., Brown, M., \& Adams, S. (1994). Men who batter: Profile from a restraining order database. Archives of Family Medicine, 3, 50-54.

Jordan, C. E. (2004). Intimate partner violence and the justice system: An examination of the interface. Journal of Interpersonal Violence, 19, 1412-1434.

Jordan, C. E., Nietzel, M. T., Walker, R., \& Logan, T. K. (2004). Intimate partner violence: A clinical training guide for mental health professionals. New York: Springer.

Jordan, C. E., Pritchard, A., Wilcox, P., \& Duckett-Pritchard, D. (2008). The denial of emergency protection: Factors associated with court decision-making. Violence \& Victims, 23, 603-616.

Kaci, J. H. (1994). Aftermath of seeking domestic violence protective orders: The victim's perspective. Journal of Contemporary Criminal Justice, 10, 201-219.

Kane, R. (2000). Police responses to restraining orders in domestic violence incidents: Identifying the custody-threshold thesis. Criminal Justice \& Behavior, 27, 561-580.

Kantor, G. K., \& Straus, M. A. (1990). Response of victims and the police to assaults on wives. In M. A. Straus \& R. J. Gelles (Eds.), Physical violence in American families: Risk factors and adaptations to violence in 8,145 families. New Brunswick, NJ: Transaction Publishers.[AQ: 3]

Keilitz, S., Hannaford, P., \& Efkeman, H. (1997). Civil protection orders: The benefits and limitations for victims of domestic violence (Publication No. R-201). Williamsburg, VA: National Center for State Courts Research.

Kethineni, S., \& Beichner, D. (2009). A comparison of civil and criminal orders of protection as remedies for domestic violence victims in a Midwestern county. Journal of Family Violence, 24, 311-321.

Kethineni, S., \& Falcone, D. N. (2001). Protective orders in domestic violence cases in a midwestern county. The Justice Professional, 14, 323-344.

Klein, A. R. (1996). Re-abuse in a population of court-restrained male batterers after two years: Development of a predictive model. In E. Buzawa \& C. Buzawa (Eds.), Domestic violence: The criminal justice response (pp. 192-213). Thousand Oaks, CA: Sage.

Logan, T. K., \& Walker, R. (2009). Civil protective order outcomes: Violations and perceptions of effectiveness. Journal of Interpersonal Violence, 24, 675-692.

Logan, T. K., Walker, R., Shannon, L., \& Cole, J. (2009). Factors associated with separation and ongoing violence among women with civil protective orders. Journal of Family Violence, 23, 377-385.

Maxwell, C. D., Garner, J. H., \& Fagan, J. A. (2001). The effects of arrest on intimate partner violence: New evidence from the Spouse Assault Replication Program. Washington, DC: U.S. Department of Justice, National Institute of Justice. 
McFarlane, J., Malecha, A., Gist, J., Watson, K., Batten, E., Hall, I., et al. (2004). Protection orders and intimate partner violence: An 18-month study of 150 black, Hispanic, and white women. American Journal of Public Health, 94, 613-618.

Mears, D., Carlson, M., Holden, G., \& Harris, S. (2001). Reducing domestic violence revictimization: The effects of individual and contextual factors and type of legal intervention. Journal of Interpersonal Violence, 16, 1260-1283.

Mignon, S. I., \& Holmes, W. M. (1995). Police response to mandatory arrest laws. Crime \& Delinquency, 41, 430-442.

Pennell, S., Burke, C., \& Mulmat, D. H. (2002). Violence against women in San Diego (NCJ 191838). Washington, DC: U.S. Department of Justice, Office of Justice Programs, National Institute of Justice.

Ptacek, J. (1999). Battered women in the courtroom: The power of judicial response. Boston: Northeastern University Press.

Robinson, A. L., \& Chandek, M. S. (2000). The domestic violence arrest decision: Examining demographic, attitudinal, and situational variables. Crime \& Delinquency, 46, 18-37.

Smith, A. (2001). Domestic violence laws: The voices of battered women. Violence \& Victims, 16, 91-110.

Spitzberg, B. (2002). The tactical topography of stalking victimization and management. Trauma, Violence, \& Abuse, 3, 261-288.

Tjaden, P., \& Thoennes, N. (2000). Extent, nature and consequences of intimate partner violence (NCJ 181867). Washington, DC: U.S. Department of Justice, Office of Justice Programs, National Institute of Justice.

U.S. Department of Justice. (2002). Enforcement of protective orders (NCJ 189190). Washington, DC: Author.

Weisz, A., Tolman, R., \& Bennett, L. (1998). An ecological study of nonresidential services for battered women within a comprehensive community protocol for domestic violence. Journal of Family Violence, 12, 395-415.

Zoellner, L. A., Feeny, N. C., Alvarez, J., Watlington, C., O’Neill, M. L., Zager, R. et al. (2000). Factors associated with completion of the restraining order process in female victims of partner violence. Journal of Interpersonal Violence, 15, 1081-1099.

\section{Bios}

Carol E. Jordan currently serves as assistant provost and director of the Center for Research on Violence Against Women at the University of Kentucky. She holds faculty appointments in the Departments of Psychology and Psychiatry. She has authored or coauthored two books, four book chapters, and numerous articles on violence against women, particularly focusing on mental health and victimization, and on experiences of women victims with the civil and criminal justice systems. She has managed grants totaling more than US\$3.5 million and since coming to the United Kingdom has built a US\$5 million research endowment. She has 25 years of experience in public policy, legislative advocacy, and research on intimate partner violence, rape, and stalking.

Adam Pritchard is a sociology doctoral student at the University of Kentucky and senior research assistant at the University of Kentucky Center for Research on Violence Against Women. He has 
coauthored several journal articles on topics, including victimization of college women, stalking, protective orders, intimate partner homicide, and perceptions of crime and risk. He is currently working on a dissertation examining perceptions of risk among dating partners.

Danielle Duckett is a doctoral candidate in the sociology program at the University of Kentucky. She is a research assistant at the Center for Research on Violence Against Women and an instructor of sociology. She completed her master's degree in 2006 with an examination of ministerial responses to domestic violence. She received the James S. Brown Fellowship for research on domestic violence in Appalachia in 2006 and is the current recipient of the Mary Byron Fellowship for work in domestic violence research.

Richard Charnigo, associate professor in the Departments of Biostatistics and Statistics at the University of Kentucky, conducts both basic and applied research. He belongs to the Administration Core of the NIH-funded (P20) Center of Research in Obesity and Cardiovascular Disease, the Administration Core of the NIH-funded (P01) Program Project in Mechanisms of Abdominal Aortic Aneurysm Formation, and the Statistics Core of the NIH-funded (P50) Center for Drug Abuse Research and Translation. He is also the principal investigator on an NSF project that develops statistical theory and methodology for nonparametric regression along with engineering methodology for nanoparticle characterization. 